\title{
ENABLING DIELECTRIC REAR SIDE PASSIVATION FOR INDUSTRIAL MASS PRODUCTION BY DEVELOPING LEAN PRINTING-BASED SOLAR CELL PROCESSES
}

\author{
Thomas Lauermann, Thomas Lüder, Sascha Scholz, Bernd Raabe, Giso Hahn, Barbara Terheiden \\ University of Konstanz, Department of Physics, 78457 Konstanz, Germany
}

\begin{abstract}
$\mathrm{Al}_{2} \mathrm{O}_{3}$ rear-passivated large-area silicon solar cells with screen-printed metallization are demonstrated for the first time.

An industrially feasible solar cell process is described that is based on printing steps to contact base and emitter of large area solar cells with dielectric rear side passivation. The base of the cell is contacted at the rear by a full area screen-printed aluminum layer on an inkjet-structured $\mathrm{Al}_{2} \mathrm{O}_{3} / \mathrm{SiN}_{\mathrm{x}}$-layer stack. The $\mathrm{Al}$ rear contacts are co-fired with the screen-printed silver front contacts. The firing temperature is reduced to limit deterioration of the passivation ability of the aluminum oxide layer. Synergies are exploited by combining the structuring steps for the formation of openings in the rear side dielectric by hydrofluoric acid with the selective emitter formation on the front side.
\end{abstract}

Investigations on lifetime samples show a 2.5-fold increase in effective lifetime for surfaces passivated by an $\mathrm{Al}_{2} \mathrm{O}_{3} / \mathrm{SiN}_{\mathrm{x}}$ stack compared to fully metalized Al-BSF rear sides. This low surface recombination velocity is combined with a low contact resistance.

On $125 \times 125 \mathrm{~mm}^{2}$ boron-doped Czochralski wafers with resistivity of $3 \Omega \mathrm{cm}$ an efficiency of $18.6 \%$ is achieved, that is a gain of $0.7 \%$ absolute compared to the efficiency of $17.9 \%$ of the best reference cells with a full area AI-BSF. An increase in the infrared spectrum of the internal quantum efficiency is determined as the source of this gain. Also, a higher reflectance at the rear side is measured that originates most probably from the $\mathrm{Si} / \mathrm{Al}_{2} \mathrm{O}_{3}$ interface.

The quality of the rear side passivation is assessed for the metalized and non-metalized area qualitatively and quantitatively. The local rear contacts are examined via scanning electron microscopy (SEM). A contact passivation mechanism based on a local BSF formation is found that is dependent on firing conditions.

\section{INTRODUCTION}

Dielectric passivation layers offer low surface recombination velocities at the rear side and hinder electrons generated in its vicinity from recombination. This leads to an increased short circuit current and contributes to a higher cell efficiency. Therefore, cell concepts employing rear side passivation schemes based on dielectric layers appear on the roadmaps of various solar cell manufacturers.

In the last years significant progress has been made in the field of surface passivation of $p$-type Si wafers. Methods like e.g. $\mathrm{Al}_{2} \mathrm{O}_{3}$ deposition via atomic layer deposition (ALD) [1] were intensively studied for photovoltaic application. $20 \times 20 \mathrm{~mm}^{2}$ cells passivated by $\mathrm{Al}_{2} \mathrm{O}_{3}$ were e.g. published by Schmidt et al. [2]. Photolithography was used to structure openings in the passivating film and the rear contact was established by Al evaporation.

The dielectric rear side passivation requires at least a partly new solar cell production process. For a solar cell manufacturer cost-effectiveness of the new technology is the main concern. Thus proven technologies as e.g. printing with a know cost structure might be preferred. Therefore we demonstrate how to translate the increased effective lifetime associated with a rear-side passivation by an $\mathrm{Al}_{2} \mathrm{O}_{3} / \mathrm{SiN}_{\mathrm{x}}$ stack into a voltage and short circuit current gain on solar cells manufactured with screen-printing metallization.

The solar cell process we introduce in this paper is based on screen-printing aluminum paste onto an inkjetstructured passivation layer consisting of $\mathrm{Al}_{2} \mathrm{O}_{3}$ and $\mathrm{SiN}_{\mathrm{x}}$. The rear Al-contact is co-fired together with the $\mathrm{Ag}$ front contact with parameters suitable to keep the passivation quality of the aluminum oxide on a high level. The passivation ability of $\mathrm{Al}_{2} \mathrm{O}_{3}$ is known to degrade when applying too high thermal budgets [3], so care has to be taken when applying a suitable firing process. Structuring synergies are exploited by combining the rear side structuring via hydrofluoric acid with a selective emitter formation on the front side as described in [4]. Both are accomplished with an industrial inkjet printer [5]. The selective emitter scheme also helps to widen the process window for front contact formation.

\section{LIFETIME AND SERIES RESISTANCE}

Lifetime and series resistance samples are fabricated on $3 \Omega \mathrm{cm}$ boron-doped Czochralski material. The $125 \times 125 \mathrm{~mm}^{2}$ large area wafers are $\mathrm{NaOH}$-etched and coated on both sides with either $30 \mathrm{~nm} \mathrm{Al}_{2} \mathrm{O}_{3}$ or a stack consisting of $15 \mathrm{~nm} \mathrm{Al} \mathrm{O}_{3}$ and $80 \mathrm{~nm} \mathrm{SiN}$. The $\mathrm{Al}_{2} \mathrm{O}_{3}$ layer is deposited in an Oxford FlexAL and the $\mathrm{SiN}_{\mathrm{x}}$ in an industrial direct plasma PECVD reactor. The operating temperature of the PECVD system is also slightly adjusted to offer ideal $\mathrm{Al}_{2} \mathrm{O}_{3}$ annealing conditions, according to [1]. Subsequently, an etch resist mask with four different point 
contact grids is applied with an inkjet printer and the dielectric layer stack is opened locally using a HF solution. A full area Al contact is screen-printed on both sides of the samples using a fritless Al paste followed by firing the samples in a belt furnace. Afterwards, the wafers are diced into $50 \times 62 \mathrm{~mm}^{2}$ pieces, each featuring one specific point contact geometry.

The samples which are passivated by a single layer of $\mathrm{Al}_{2} \mathrm{O}_{3}$ without the protecting $\mathrm{SiN}_{\mathrm{x}}$ layer show a largely destroyed $\mathrm{Al}_{2} \mathrm{O}_{3}$ layer after metallization etch-back. Al pastes contain agents that react chemically with the $\mathrm{Al}_{2} \mathrm{O}_{3}$ layer during firing. These agents are responsible for interconnecting the $\mathrm{AlO}_{\mathrm{x}}$-coated $\mathrm{Al}$ particles in the paste as described in [6]. Therefore the single-layer approach is discarded for the experiments on cell level and all $\mathrm{Al}_{2} \mathrm{O}_{3}$ rear sides receive a capping PECVD $\mathrm{SiN}_{\mathrm{x}}$ layer which was shown to remain intact during the firing process.

After performing series resistance measurements between the front and the back contact, the Al paste is etched off in $\mathrm{HCl}$ solution to enable lifetime measurements by quasisteady-state photoconductance (QSSPC).

\begin{tabular}{|c|c|c|c|}
\hline $\begin{array}{l}\text { Via width } \\
{[\mu \mathrm{m}]}\end{array}$ & Pitch & $R_{s}[m \Omega]$ & eff. $\tau$ [ $\mu s]$ \\
\hline 300 & Wide & 19.4 & 18.1 \\
\hline 200 & Wide & 25.9 & 25.9 \\
\hline 100 & Narrow & 20.2 & 16.4 \\
\hline 60 & Narrow & 34.6 & 20.8 \\
\hline \multicolumn{2}{|c|}{ Full area Al-BSF reference } & 4.5 & 10.5 \\
\hline
\end{tabular}

Table 1: Effective lifetimes of the samples passivated with an $\mathrm{Al}_{2} \mathrm{O}_{3} / \mathrm{SiN}_{\mathrm{x}}$ stack on both sides. The dielectric layer is locally opened, the Al paste is alloyed and subsequently the residues are etched off. The overall series resistance of the corresponding samples with both sides still contacted is also given.

The data of table 1 show that the effective lifetimes as determined after the firing process are in all cases higher for the dielectrically passivated samples than for the samples with a full area Al-BSF passivation. The size of the local openings in the dielectric $\mathrm{Al}_{2} \mathrm{O}_{3} / \mathrm{SiN}_{\mathrm{x}}$ stack affects the lifetime and series resistance. The smaller openings are causing a larger resistance. Also, a narrower spacing causes a lower effective lifetime. Therefore, a wide pitch and via widths above $200 \mu \mathrm{m}$ are selected as the most promising candidates for solar cell fabrication. The impact on the series resistance of the final solar cells is discussed with the cell results.

\section{SOLAR CELL FABRICATION}

For the fabrication of solar cells, a selective emitter structure [4] is chosen for the front side of the $3 \Omega \mathrm{cm}$ boron-doped $125 \times 125 \mathrm{~mm}^{2} \mathrm{Cz}$-Si wafers with an alkaline texture. Emitter profile and pastes are chosen to achieve a broad process window for front contact formation. These measures help to adapt the firing parameters since it is known that $\mathrm{Al}_{2} \mathrm{O}_{3}$ layers can lose some of their passivating abilities when being processed at too high temperatures [3].

\begin{tabular}{|c|c|}
\hline References & Passivated Cells \\
\hline \multicolumn{2}{|c|}{ Alkaline Texture } \\
\hline \multicolumn{2}{|c|}{ Strong emitter diffusion } \\
\hline & Chemical polish rear \\
\hline & $\mathrm{Al}_{2} \mathrm{O}_{3}$ and $\mathrm{SiN}_{\mathrm{x}}$ deposition \\
\hline Inkjet masking front ... & $\ldots$ and rear \\
\hline Sel. emitter formation... & ... and via etching \\
\hline \multicolumn{2}{|c|}{ PECVD SiN ARC } \\
\hline \multicolumn{2}{|c|}{ Screen printing $\mathrm{Ag}$ front grid and full $\mathrm{Al}$ rear side } \\
\hline \multicolumn{2}{|c|}{ Co-firing } \\
\hline
\end{tabular}

Table 2: Process flow chart for dielectrically passivated solar cells and full area BSF references.

The cells receive an alkaline texture and a strong $\mathrm{POCl}_{3}$ diffusion. Afterwards, the edges are insulated by plasma etching. The rear sides are chemically polished, $\mathrm{HCl} / \mathrm{HF}$ cleaned and coated with an $\mathrm{Al}_{2} \mathrm{O}_{3} / \mathrm{SiN}_{x}$-stack. Subsequently front and rear side etch resist printing is carried out using an industrial inkjet printer [5] before immersion in the acidic structuring solutions. With this processing sequence industrial applicability is taken into account by exploiting synergetic effects when structuring front and rear side at the same time, since etching, resist stripping and cleaning, which are already part of the selective emitter process, need to be done only once in the process.

After structuring, a PECVD $\mathrm{SiN}_{\mathrm{x}}$ anti-reflection coating is applied to the front side. Al paste is printed on the full rear side area as described for the lifetime samples, before the paste is fired together with the front contacting paste in a belt furnace. Two sets of firing parameters $A$ and $B$ are tested. All pastes used are commercially available.

\section{SOLAR CELL RESULTS}

The finished cells show the following IV characteristics.

\begin{tabular}{|c|c|c|c|c|}
\hline & $\begin{array}{c}\mathbf{J}_{\text {sc }} \\
{\left[\mathbf{m A} \mathbf{c m}^{2} \text { ] }\right.}\end{array}$ & $\begin{array}{c}\text { FF } \\
{[\%]}\end{array}$ & $\begin{array}{c}\mathbf{V}_{\text {oc }} \\
{[\mathbf{m V}]}\end{array}$ & $\begin{array}{c}\text { Eta } \\
{[\%]}\end{array}$ \\
\hline Ref. & 36.4 & 79.5 & 619.1 & 17.9 \\
\hline Ref. & 36.5 & 78.9 & 618.2 & 17.8 \\
\hline Pass. A & 37.2 & 78.4 & 628.7 & 18.3 \\
\hline Pass. A & 37.5 & 77.6 & 629.5 & 18.3 \\
\hline Pass. B & 37.8 & 77.2 & 638.6 & 18.6 \\
\hline Pass. B & 38.0 & 76.9 & 637.8 & 18.6 \\
\hline
\end{tabular}

Table 3: Cell results $\left(125 \times 125 \mathrm{~mm}^{2} \mathrm{Cz}, 3 \Omega \mathrm{cm}\right)$ of the best references compared to the best $\mathrm{Al}_{2} \mathrm{O}_{3}\left(\mathrm{SiN}_{x}\right.$ passivated cells. A selective emitter structure is chosen for both groups with screen-printing of $\mathrm{Ag}$ on the front and $\mathrm{Al}$ on the rear side. 
The dielectrically passivated solar cells exhibit a lower fill factor compared to the cells with a full area AI-BSF. One reason is the increased series resistance for the locally contacted cells. It can be extracted from the IV curves to about $0.6 \Omega \mathrm{cm}^{2}$ for the locally contacted cells compared to $0.5 \Omega \mathrm{cm}^{2}$ for the references.

However, the dielectrically passivated solar cells reach significantly higher values for open circuit voltage and shortcircuit current density. The origin of this gain in $J_{s c}$ is analyzed by a spectral response measurement as shown in Fig. 1.

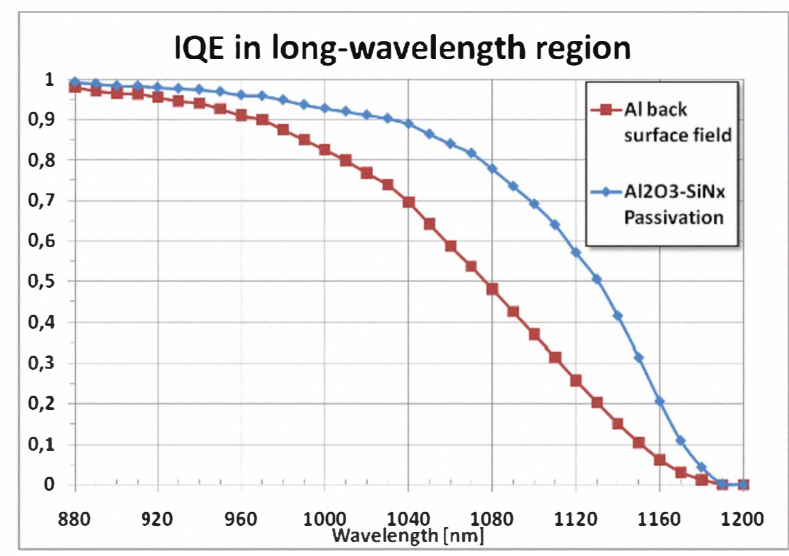

Figure 1: Infrared internal quantum efficiencies of a reference cell compared to a dielectrically rear-passivated cell. The IQE in the visible region is virtually identical for both cell types.

A gain of $26 \%$ relative in the internal quantum efficiency between $900 \mathrm{~nm}$ and $1200 \mathrm{~nm}$, where the rear surface recombination influences the $I Q E$, is determined.

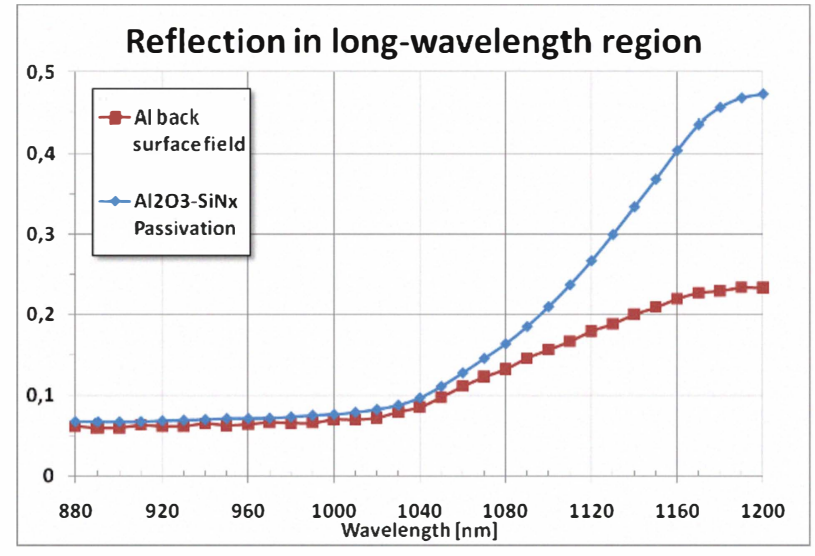

Figure 2: Reflectance curves of the solar cells. Dielectrically passivated rear sides show a higher rear surface reflectance.
A part of the $J_{s c}$ gain can also be attributed to better light confinement within the solar cell. Rear sides formed by firing Al paste are known for absorbing a great deal of the light that passes through the wafer [6]. In contrast, the cells with the dielectric passivation stack between the silicon and the paste show enhanced reflectance values in the infrared wavelength range (see Fig. 2).

This means that the passivating layers act as internal reflectors even when combined with fired Al paste, giving the incident photons above $980 \mathrm{~nm}$ a higher probability to be absorbed in the active Si bulk material. Typical infrared reflectances, as fitted from the spectral response data, are around $90 \%$ with a lambertian factor of about 0.9 compared with full Al rear sides that show reflectances around $70 \%$.

When applying the AM1.5 spectrum to the measured IQE and reflectance, the $J_{s c}$ gain achieved by improved optics can be calculated to $0.8 \mathrm{~mA} / \mathrm{cm}^{2}$ and the $J_{s c}$ gain by less rear side recombination is estimated to $0.8 \mathrm{~mA} / \mathrm{cm}^{2}$. These calculations show good accordance with the measured $J_{s c}$ differences between stack-passivated and reference solar cells of about $1.5 \mathrm{~mA} / \mathrm{cm}^{2}$.

\section{REAR SIDE LOSS ANALYSIS}

Investigation by laser beam induced current (LBIC) on the finished cells at a wavelength of $980 \mathrm{~nm}$ reveals the quality of the rear side passivation, which has, as suggested by the spectral response data, an IQE close to $100 \%$. However, the limiting factor of the rear side is the surrounding region of the point contacts. Fig. 4 shows an example where insufficient passivation at the contact region affects a major areal fraction of the cell rear side. It is fired with rather conservative firing parameters, described as " $A$ " before.

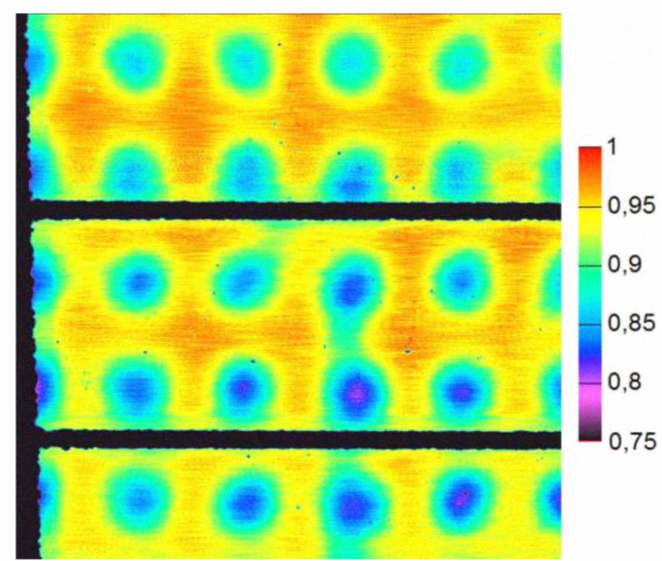

Figure 3: IQE @ $980 \mathrm{~nm}$ of a cell from batch A with poorly passivated contact regions. The whole surrounding of each contact is affected.

In contrast, on cells produced with firing parameters better suited for local BSF formation, the drop in IQE around the 
contacts is much less pronounced. It stems from the batch called " $B$ ", its rear-side quality can be evaluated in Fig. 4:

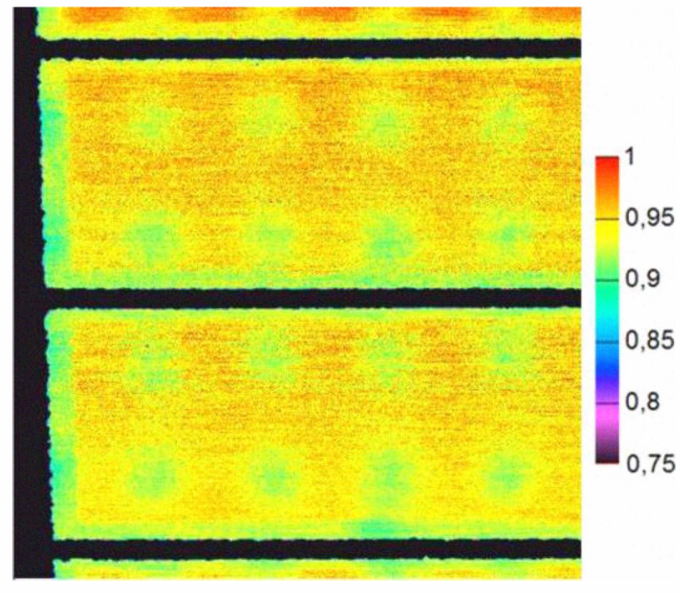

Figure 4: IQE @ $980 \mathrm{~nm}$ of a cell from batch B with sufficiently passivated contact regions.

Here, the local IQE drops only moderately to values around $90 \%$. Such values at $980 \mathrm{~nm}$ correspond to the IQE achieved by a full-area BSF. It is therefore suggestive that the rear contacts of the latter cell feature a passivation mechanism based on $\mathrm{p}^{+}$doping while the contacts in the first cell lack significant passivation. This behavior can be quantified by determination of their respective rear surface recombination velocities (RSRV).

According to Fischer [7], an effective rear surface recombination velocity $\left(S_{\text {eff }}\right)$ for locally contacted solar cells can be defined that corresponds to the RSRV a cell with equal spectral response but uniform RSRV would show. It can be obtained by combining the SRV of the passivating layers $\left(S_{\text {pass }}\right)$ with the SRV of the metallized area $\left(S_{\text {met }}\right)$ in the following way:

$S_{\text {eff }}=\frac{D}{W}\left[\frac{p}{2 W \sqrt{\pi f}} \arctan \frac{2 W}{p} \sqrt{\frac{\pi}{f}}-e^{-\frac{W}{p}}+\frac{D}{f W S_{\text {oret }}}\right]^{-1}+\frac{S_{\text {pass }}}{1-f}$

Here, Wis the wafer thickness, $D$ the diffusion constant, $p$ the contact pitch and $f$ the metallization fraction. It holds under the assumptions that both bulk diffusion length and contact pitch is greater than wafer thickness, which is valid for the used $\mathrm{Cz}$ substrates. Low-injection conditions are also assumed.

From the spectral response measurements, the following values of $S_{\text {eff }}$ can be extracted by the fitting procedure after Basore [8]. The results can be found in Table 4.

\begin{tabular}{|c|c|}
\hline Solar Cells & S $_{\text {eff }}[\mathbf{c m} / \mathbf{s}]$ \\
\hline Full-Al-BSF references & $650-1000$ \\
\hline $\mathrm{Al}_{2} \mathrm{O}_{3}-$ Pass. batch A & $240-320$ \\
\hline $\mathrm{Al}_{2} \mathrm{O}_{3}-$ Pass. batch B & $140-190$ \\
\hline
\end{tabular}

Table 4: Effective rear surface recombination velocities for different cell types.

Since $S_{\text {eff }}$ is now fixed, the values for $S_{\text {met }}$ can be calculated from the Fischer equation if we assume reasonable values for $S_{\text {pass }}$ after firing. These are determined by firing lifetime samples with an identical passivation stack at the same peak temperatures (measured on the wafer surface). An upper limit of 60 $70 \mathrm{~cm} / \mathrm{s}$ is found for the SRV of a sample with $\mathrm{Al}_{2} \mathrm{O}_{3} / \mathrm{SiN}_{x}$ surface passivation after firing.

Numerical solution suggests values of $S_{\text {met }}$ in the order of $10^{5} \mathrm{~cm} / \mathrm{s}$ for batch $A$ and around $1500 \mathrm{~cm} / \mathrm{s}$ for batch $B$. It can be easily deducted that the limiting factor in case $A$ are the metal contacts themselves in contrast to case B, where a lowering of $S_{\text {pass }}$ still has a major impact on $S_{\text {eff. }}$

\section{SEM CONTACT AREA INVESTIGATION}

Apparently the SRVs of the differently fired contacts vary by two orders of magnitude. For this reason, the contacts themselves deserve a closer look. The solar cells are broken along their crystal orientation and the crosssections are examined with a scanning electron microscope (Zeiss Neon EsB CrossBeam).

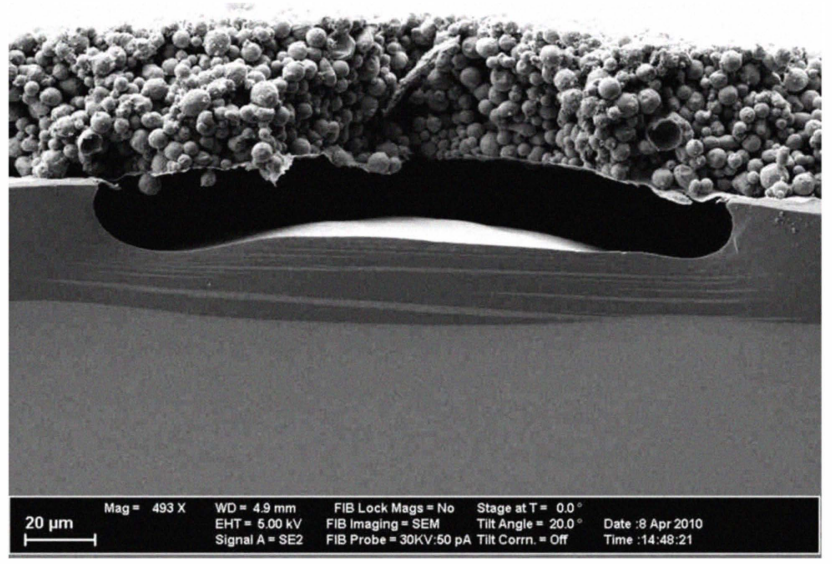

Figure 5: Cavern visible beneath each contacting spot.

The most striking feature of every contact was the cavern formed under each contact opening during alloying. This behavior comes from the high solubility of $\mathrm{Si}$ in the $\mathrm{Al}$ of the paste at temperatures above the eutectic point $\left(577^{\circ} \mathrm{C}\right.$, $12 \% \mathrm{Si}$ ) [9]. The $\mathrm{Si}$ in the paste tries to reach an equilibrium concentration at its temperature-dependent solubility level over the whole rear side. Since the only sources of silicon for the melt are available beneath the 
contact points, a transport occurs as illustrated in Fig. 6 which leads to local out-diffusion of dissolved silicon into the paste.

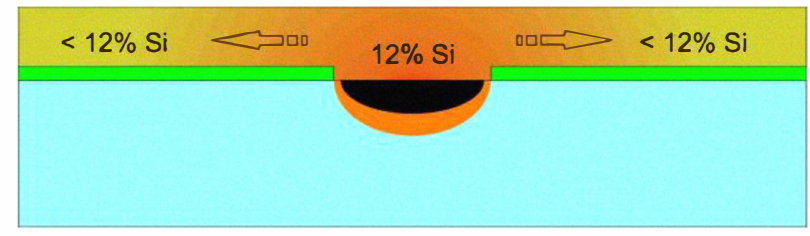

Figure 6: Out-diffusion of dissolved Si (red) from the wafer bulk (blue) under the contact spots into the Al paste (yellow). Green: $\mathrm{Al}_{2} \mathrm{O}_{3} / \mathrm{SiN}_{\mathrm{x}}$ stack

This behavior was reported before [10] and can hardly be avoided. It can, however, be influenced by the size of the opening, because contacts larger than $200 \mu \mathrm{m}$ reach a saturation of $\mathrm{Si}$ in $\mathrm{Al}$ in their middle part and there the $\mathrm{Al}$ remains in contact with the wafer.

This also affects contact properties and passivation, since a bare Si flank is supposed to have an enormous recombination velocity. In order to search for the passivation mechanism apparently present in the samples from group $B$, SEM images are taken with the InLens detector. These images contrast the electronic structure and therefore allow to draw conclusions about the size of differently doped regions like an AI-BSF.

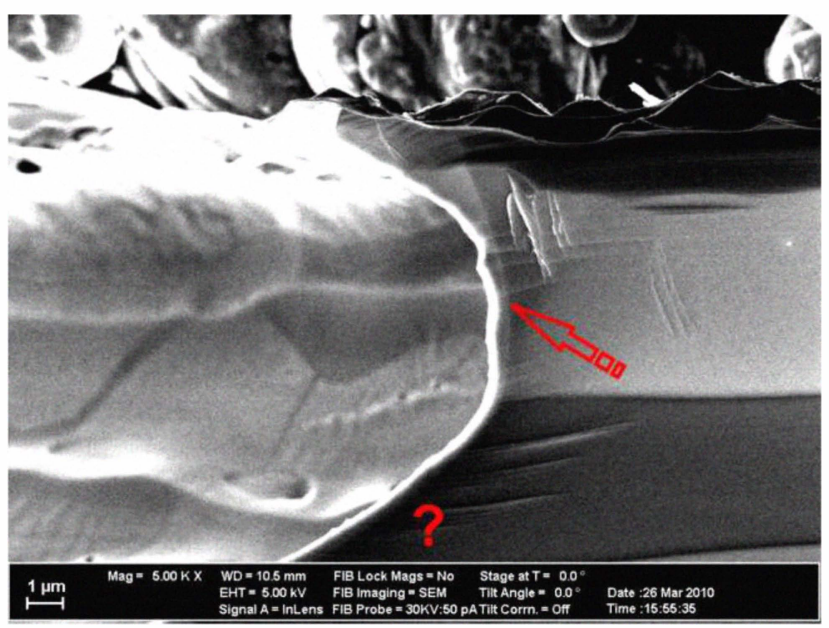

Figure 7: The contacts from batch $A$ show a very thin $(<1 \mu \mathrm{m})$ and low-contrast $\mathrm{p}^{+}$-region that appears only at the sides of the cavern. The arrow points at the doping contrast border.

Fundamental differences between batch $A$ and batch $B$ can be found not so much in cavern size and shape, but in BSF thickness and coverage. While the caverns in batch $A$ show only very thin BSF layers with a low doping contrast at the cavern flanks and no detectable doping contrast at the bottom of the caverns (see Fig. 7), the situation is very different with batch $B$. The doping contrast is more pronounced, the width of the $\mathrm{p}^{+}$-region spans several $\mu \mathrm{m}$ and the BSFs are enveloping the whole caverns (see Fig. 8). Under such conditions, no unpassivated metal surface is in contact with the Si bulk.

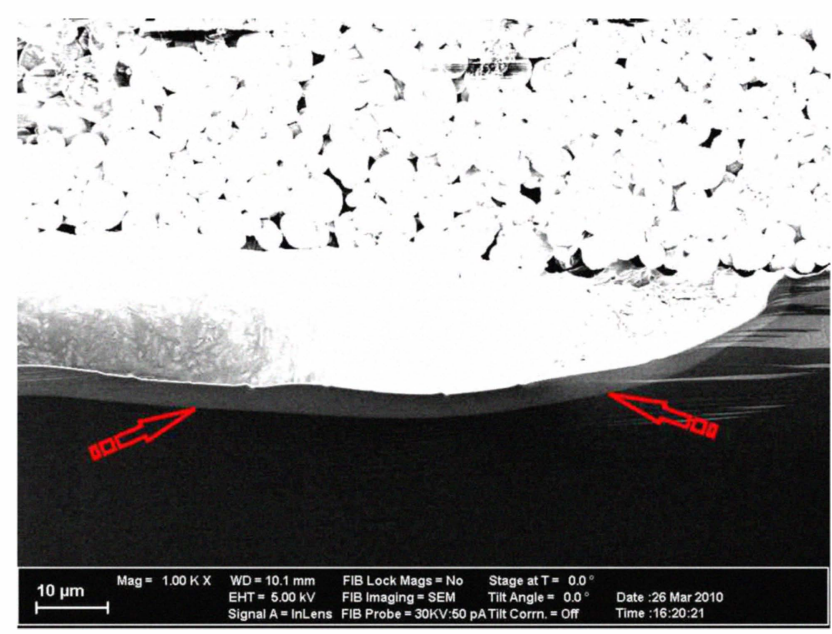

Figure 8: At this contact from batch $B$ an approximately 4$6 \mu \mathrm{m}$ thick BSF is clearly visible around the whole cavern.

The fill factor differences between the locally contacted cells can also be explained by different contact properties. In some samples, the caverns are found to be partially filled with Al-Si-alloy. In this case, the contact resistance between $\mathrm{Al}$ and $\mathrm{Si}$ is lowered since the alloy has a large contact area compared to the empty caverns that are contacted only at the flanks. The best fill factor achieved in this batch was $79.0 \%$ which is remarkable for a locally contacted cell with a local BSF.

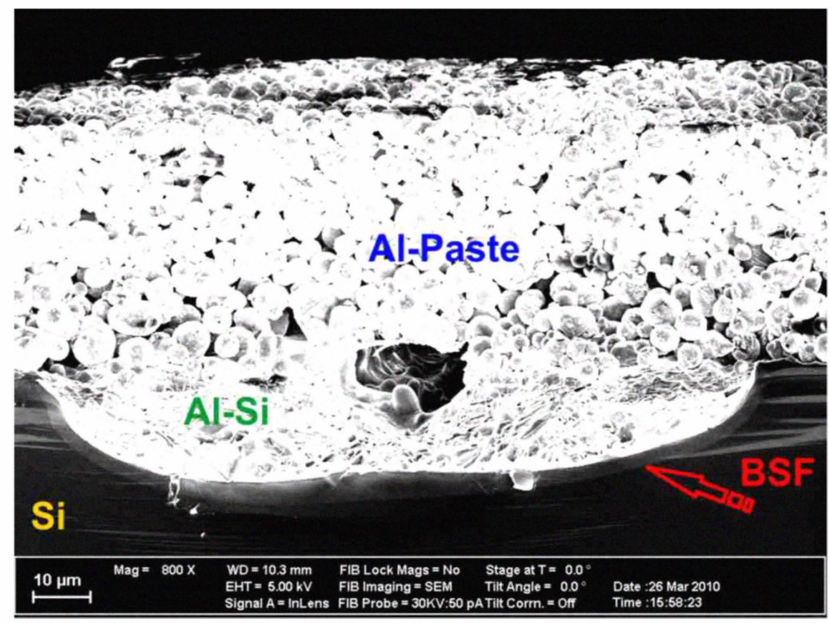

Figure 9: The rear contacts from another cell in batch $B$ show partially alloy-filled caverns with full contact to an enveloping BSF.

From these observations it can be deduced that the firing parameters have to be adjusted towards alloying conditions that retain sufficient amounts of Si-rich alloy 
around the contacts so that a BSF can be formed epitactically during cooling. These requirements are met with batch $\mathrm{B}$, in contrast to the close-to-standard firing conditions applied to batch $A$ that show insufficient local BSF formation. The unpassivated metal-Si interfaces at the contact sites show increased recombination that partially offsets the gains won by the $\mathrm{Al}_{2} \mathrm{O}_{3}$ passivation.

\section{SUMMARY}

A solar cell manufacturing process is developed to fabricate solar cells with dielectric rear side passivation that are metallized by means of screen-printing. The back contacts are established by firing Al paste through local openings in the passivating layers. These openings are structured by inkjet printing and wet chemical etching.

This is the first time that screen-printed $\mathrm{Al}_{2} \mathrm{O}_{3} / \mathrm{SiN}_{\mathrm{x}}$ passivated solar cells on large-area p-type wafers are reported. Efficiencies of up to $18.6 \%$ are achieved thanks to a gain in $J_{s c}$ originating from a higher internal quantum efficiency and enhanced reflection in the long-wavelength end of the spectrum.

The co-firing produces caverns at the local contact areas. Their size and shape is dependent on the dimensions of the vias in the passivating layers. However, acceptable fill factors and a local passivation of the point contacts are found. These beneficial properties can be attributed to the formation of a BSF by alloying in the contacting areas that is observable by SEM. The BSF lowers the local surface recombination velocity of the contacts by two orders of magnitude. This process and the resulting overall passivation quality, made visible by LBIC, strongly depends on the choice of suitable firing parameters and is quite independent of the via size.

\section{ACKNOWLEDGEMENTS}

The authors would like to thank L. Rothengaß, S. Ohl, B. Rettenmaier, J. Ruck, F. Mutter, C. Gründler, A. Zuschlag and V. Mayer for their support during cell processing and characterization. The financial support from the German BMU FKZ 0325168 and FKZ 0325079 is gratefully acknowledged. The content of this publication is the responsibility of the authors.

\section{REFERENCES}

[1] B. Hoex, S.B.S. Heil, E. Langereis, M.C.M. van de Sanden, W.M.M. Kessels: "Ultralow surface recombination of $\mathrm{C}$-Si substrates passivated by plasma-assisted atomic layer deposited $\mathrm{Al}_{2} \mathrm{O}_{3}$ ", Appl. Phys. Lett. 89, 2006, 042112

[2] J. Schmidt, A. Merkle, R. Brendel, B. Hoex, M.C M. van de Sanden, W.M.M. Kessels: "Surface passivation of highefficiency silicon solar cells by atomic-layer-deposited $\mathrm{Al}_{2} \mathrm{O}_{3}{ }^{\prime \prime}$, Prog. Photovolt. Res. Appl. 16, 2008, pp. 461-466
[3] J. Benick, A. Richter, M. Hermle, S.W. Glunz: "Thermal stability of the $\mathrm{Al}_{2} \mathrm{O}_{3}$ passivation on p-type silicon surfaces for solar cell applications", physica status solidi RRL 3, 2009, 7-8 pp. 233

[4] A. Dastgheib-Shirazi, H. Haverkamp, B. Raabe, F. Book, G. Hahn: "Selective emitter for industrial solar cell production: A wet chemical approach using a single diffusion process", Proc. 23rd EU PVSEC, Valencia 2008 pp. 1197

[5] T. Lauermann, A. Dastgheib-Shirazi, F. Book, B. Raabe, G. Hahn, H. Haverkamp, D. Habermann, C. Demberger, C. Schmid: "inSECT: An inline selective emitter concept with high efficiencies at competitive process costs improved with inkjet masking technology", Proc. 24th EU PVSEC, Hamburg 2009, pp. 1767

[6] F. Huster: "Investigation of the alloying process of screen printed aluminium pastes for the BSF formation on silicon solar cells", Proc. 20th EU PVSEC, Barcelona 2005, pp. 1466

[7] B. Fischer: "Loss analysis of crystalline silicon solar cells using photoconductance and quantum efficiency measurements", Ph.D. thesis, University of Konstanz, 2003

[8] P.A. Basore: "Extended spectral analysis of internal quantum efficiency", Proc. 23rd IEEE PVSC, Louisville 1993; pp. 147-152

[9] J.L. Murray and A.J. McAlister "The Al-Si System", Bulletin of alloy phase diagrams 5, No. 1, 1984, pp. 74

[10] V. Meemongkolkiat, K. Nakayashiki, D.S. Kim, S. Kim, A. Shaikh, A. Kuebelbeck, W. Stockum, A. Rohatgi: "Investigation of modified screen-printing Al pastes for local back surface field formation", Proc. 4th WCPEC, Hawaii 2006, pp. 1138 